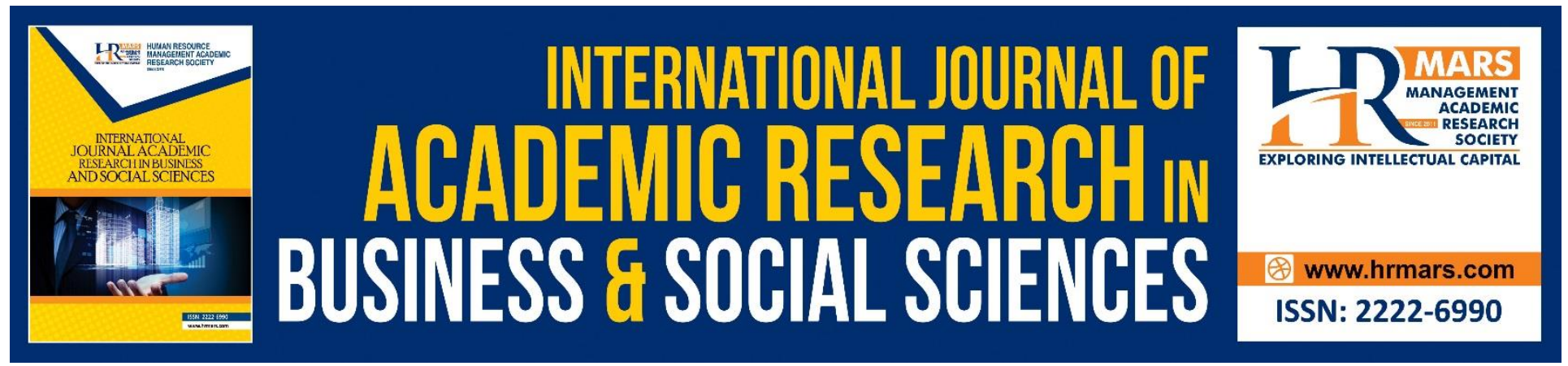

\title{
The Contribution of 'Tarbiyah' as Organizational Learning Mechanism towards the Sustainability of an Islamic-based Non-Governmental Organization and the Larger Community Wellbeing in Malaysia
}

Shaikh Mansoor Bin Shaikh Ahmad, Ismi Arif Ismail, Siti Noormi Binti Alias

To Link this Article: http://dx.doi.org/10.6007/IJARBSS/v11-i15/10643 DOI:10.6007/IJARBSS/v11-i15/10643

Received: 14 May 2021, Revised: 19 June 2021, Accepted: 05 July 2021

Published Online: 20 July 2021

In-Text Citation: (Ahmad et al., 2021)

To Cite this Article: Ahmad, S. M. B. S., Ismail, I. A., \& Alias, S. N. B. (2021). The Contribution of 'Tarbiyah' as Organizational Learning Mechanism towards the Sustainability of an Islamic-based Non-Governmental Organization and the Larger Community Wellbeing in Malaysia. International Journal of Academic Research in Business and Social Sciences, 11(15), 166-173.

\section{Copyright: (c) 2021 The Author(s)}

Published by Human Resource Management Academic Research Society (www.hrmars.com) This article is published under the Creative Commons Attribution (CC BY 4.0) license. Anyone may reproduce, distribute, translate and create derivative works of this article (for both commercial and non-commercial purposes), subject to full attribution to the original publication and authors. The full terms of this license may be seen at: $\underline{\text { http://creativecommons.org/licences/by/4.0/legalcode }}$

Special Issue: Empowering Youth and Community Wellbeing for Sustainable Development, 2021, Pg. 166 - 173 


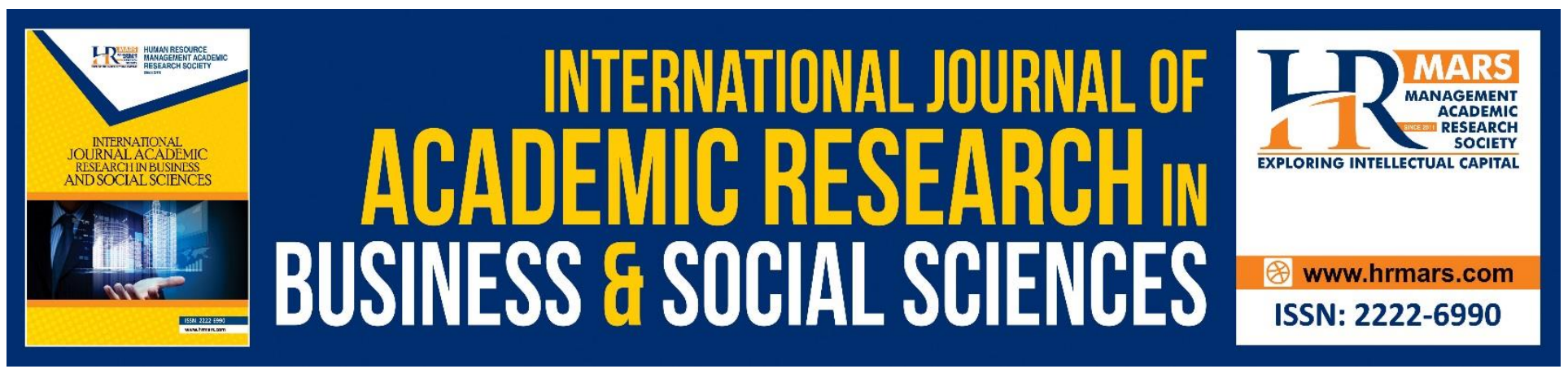

\title{
The Contribution of 'Tarbiyah' as Organizational Learning Mechanism towards the Sustainability of an Islamic-based Non-Governmental Organization and the Larger Community Wellbeing in Malaysia
}

\author{
Shaikh Mansoor Bin Shaikh Ahmad \\ Faculty of Educational Studies Universiti Putra Malaysia (UPM) \\ Email: smansoor1954@gmail.com \\ Ismi Arif Ismail \\ Institute for Social Science Studies (IPSAS) Universiti Putra Malaysia \\ Email: ismi@upm.edu.my
}

Siti Noormi Binti Alias

Faculty of Educational Studies Universiti Putra Malaysia

Email: sitinoormi@upm.edu.my

\begin{abstract}
Organizational learning concept was used in developing organizations since early $20^{\text {th }}$ century. Organizations are made of various communities within them. Community of Practice (CoP) are group of peoples who share a concern or a passion for something they do and learn how to do it better as they interact regularly. Organizational learning activities in the form of intellectual discourses or 'Tarbiyah' in the context of this study, act as a social learning input that developed activists' mind, body and heart holistically in order for them to practice Islam as a way of life. This study employed a qualitative narrative research approach involving nine participants, six from Selangor and three from Penang Islamic-based Non-Governmental Organization. Result indicated that the 'Tarbiyah' affected on participants' optimism for volunteering and self-satisfaction. It affected on their passion to contribute more as it provided a boost to their self-esteem. In essence, 'Tarbiyah' provide a powerful organizational learning model for this Islamic-based NGO which contributes to changes in individual and organizational behaviour. 'Tarbiyah' in the CoP of the NGO led individuals to co-learn, share knowledge and enrich their repertoire of becoming a better organization members and eventually enhance the larger community wellbeing.
\end{abstract}

Keyword: Tarbiyah, Communities of Practice, Organizational Learning, Learning Organization, Community Wellbeing. 


\section{Introduction}

Organizational Learning (OL) concept was used in developing organizations since the early $20^{\text {th }}$ century (Watkins \& Marsick, 1997; Britton, 2005). Organization is made of various community of practices and these are groups of people who share a concern or a passion for something they do and learn how to do it better as they interact regularly (Wenger, 1998). In this article, one Islamicbased NGO is considered as a CoP entity since they learn and contribute voluntarily to develop themselves and the larger community in their welfare activities. The NGO is also a Learning Organization (LO) that provides tarbiyah (education) to develop their members to learn and practice Islam as a way of life or addin.

The development of many Islamic-based CoP activists started since 1970's using the concept of tarbiyah (education) as OL programme introduced by Hasan al-Banna in 1948 (Elsasser, 2014). Usrah in tarbiyah is a study circle or meeting of 3-10 members weekly, led by a leader or Naqib to inculcate the value of Islamic teaching and its practices in their daily life (Shaari \& Jamaluddin, 2011).

Usrah meeting is the smallest CoP unit of activities in this Islamic-based NGO where members interact and learn informally from one another on weekly basis. Tarbiyah model as a social learning concept have developed activists mind, body and heart holistically in order for them to practice Islam as a way of life. The social learning experiences among this Islamic-based CoP activists in Malaysia involve multiple activities to increase their spiritual knowledge and to metaphorically 'purify' their heart, body and soul (Al Ghazzali, 2020).

Moten (2011) defines leadership as the influence of power, direction and control related to leaders and followers. Leadership from an Islamic perspective refers to the influencing everyone towards believing in the creator Allah SWT as the only power that controls everything (Elsasser, 2014). The role of Naqib as a leader in the tarbiyah within the Islamic-based NGO is to educate everyone including oneself to remain steadfast and to sustain the community connectedness in the organization. As a murabbi or living example, a naqib plays an important role in the development of the knowledge, skills and potential of members in the usrah circle.

The tarbiyah that develops Naqib and members in the Islamic-based NGO CoP activists conform to the apprenticeship concept (Brown, Collins and Duguid, 1989) in which individual learn from another in a group. The apprenticeship concept stem from the situated learning and social learning theories (Lave and Wenger, 1991). According to Senge (1990), OL occurs when there are individuals who are willing to help and also learn from other individuals to develop new knowledge and skills.

This theory is based on the social concept of 'legitimate peripheral participation' in which novice and expert co-curate the knowledge and skills to unleash and enhance the potential of members in the organization. The Islamic-based NGO CoP activists acquire Islamic knowledge and skills through their participation in the usrah circle. After that, the leader of the usrah or naqib will approve the presence of new member into the Islamic-based NGO usrah circle. This member who was initially on the peripheral as novice will be mentored and facilitated before moving into becoming the regular and active member contributing to the organization. The legitimacy of being absorbed into becoming an active member with greater responsibilities within the organization will be decided by the naqib with the help of other usrah members is very much similar to the 'novice to expert movement' in the apprenticeship model practiced by CoP in other organizations (Pyrko et al., 2017). 


\section{Methodology}

Qualitative research approach was employed to explore the experiences of the NGO activists. Semi structured interviews were conducted with nine (9) NGO activists at the mosques, their home and offices until reaching saturation point of information. Besides interviewing, the researcher also triangulate the data collection by performing a number of participant observations during the NGO activities. Document analysis also was employed to complement these two data collection techniques.

The data analysis were carried out manually and simultaneously during the data collections (Merriam, 2009) using the constant comparative method (Boeije, 2002). The data were then developed into codes, categories and themes. Once the emerging themes were finalised, the researcher conducted the data verification or member checks with some informants who volunteered to help. Audit trail, peer examination and triangulation also helped the researcher to enhance the reliability, validity and trustworthiness of the study. The findings of this study yielded a number of themes related to the contribution of tarbiyah towards sustaining the Islamic-based NGO in Malaysia.

\section{Result and Discussion}

In exploring the organizational learning process in an organization, we humbly made use of Peter Senge's theoretical explanation of the five "disciplines" that facilitate the development and empowerment of a learning organization and its members.

\section{Systems Thinking}

System thinking is the "conceptual cornerstone" underlying all the other disciplines in the making of a learning organization (Senge, 2006, p. 69[3]). A learning organization is an organization where members are given the opportunity to voice their ideas, to collectively decide on their expected action and common results through learning on how to learn together as a team (Senge, 2006, p. 3). Each and everyone shares responsibility for problems generated by a system (Senge, 2006, p. 78) and this shared responsibility are the results of the workings within a system tied by a common philosophy and practices (Owen et al., 2013).

The Islamic-based NGO convention every two years give activists the opportunity to voice their ideas and select leaders of their choice. Respondent Dr P stated: "... the organization hold election of leaders at the district, state and national levels ... members have their right to vote for appropriate leaders of their choice ...". The right and opportunity to choose leaders of their choice through discussions and guided by the Tarbiyah is one major factor that contributed to the sustainable of the activists in the NGO. The Tarbiyah continuously set the systems thinking within the NGO and this is the glue that ties the members together in working towards a common goal.

It is the responsibility of the naqib to guide and develop members in usrah to a higher level in the Islamic-based NGO structure by given them appropriate responsibilities. It has three major branches in which the members could contribute their potential and interest which are: tarbiyah (education), dakwah (spreading of Islamic awareness) and welfare (charity activities). Naqib or murabbi (good example) is a source of reference to the members in usrah. Respondent $J$ explained this shared responsibility by referring to the Muslim Brotherhood Organization in Egypt led by Imam Hassan alBanna and also through the history of the Prophet Muhammad (saw): 
“... I developed myself from the Hasan al-Banna school ... which is a school without a roof... no formal building ... as in the time of the Prophet Muhammad (saw). Rasulullah developed his sahabah ... with tarbiyah so that they were able to conquer the Roman and Persian colonies. It is not easy to train quality leadership with concern and passion characteristics. Naqib must set the best example. Naqib has a profound effect and confidence in members to continue to be in the organization ..."

Naqib helped respondent $L$ by discussing and solved the problem in the shura council. This experience has taught respondent $L$, a valuable lessons for him to remain in the organization. Respondent $L$ and his naqib or leader discussed again how to overcome the mistake done earlier. The role of leadership is one of the important factors that keep members to share the responsibility within the organization. On the same note, Senge appreciates and emphasises on the the importance of inter-organizational learning, asserting that: "One could argue that the entire global business community is learning to learn together, becoming a learning community" (Senge, 2006, p. 4).

\section{Personal Mastery}

Tarbiyah also develop the activists' personal mastery as naqib set a leadership and role model that supports, helps and guide the members so that they succeed together. This leadership concept is the a benchmark for respondent J. Respondent J explained: " ...there is difference in leadership in a normal organization compared to the leadership practiced in this NGO ... if we lead in NGO... we are not in the front position... we hold the hand of the person we lead next to us ... and lead him across the road together ... This is the kind of leader we choose... we move forward together..."

This is an example of how a leader develop members' personal mastery to eventually lead the organization together, providing check and balance and understanding one's role as a member.

According to Senge (2006), personal mastery is about continuously illuminating what is important to everyone and why we are in this together in the first place. Personal mastery answers the why question to each and every member's involvement in the NGO and this is achieved through the continuing tarbiyah exercise conducted from time to time throughout their usrah and other social activities. Tarbiyah also educates members to continuously learn how to see their internal and external reality in a clear perspective.

Senge highlights the importance of developing one's personal mastery to see how one connects to both the physical and spiritual worlds. On personal mastery especially, Senge focuses on teaching us about caring (Hansen et al. 2020), whereas the tarbiyah in this NGO add on with concern and passion. These three concepts are always aligned to their connectivity to the creator Allah SWT. In other words, each member continue learning to master not only about one's religious belief system and practices, but also on how to care, to show one's concern and passion for others for the sake of Allah SWT. This personal mastery of managing your relationship to other human being and your relationship to Allah SWT sustains their commitment and love for their NGO and the larger community wellbeing.

\section{Mental Models}

Tarbiyah also nurtures one's mind and worldview. It is in line with Senge's "mental models" discipline which requires one to develop a sense of awareness of one's own worldview and how this view is continuously updated, refresh and refined to inform one's thought, decision and actions. The practice of updating one's mental models converges with the tarbiyah outcome of having each NGO member 
to reflect and revive one's assumptions, opinions and conversations with others and God. The significance of dialogue and discourse in the usrah as a vehicle for Tarbiyah provides the opportunity for legitimate peripheral participation (Lave and Wenger, 1991) as well as sustaining one's involvement and inclusion in the NGO. A learning organization like this will then has the capability, internally and externally to link to the larger community. Looking at tarbiyah as an OL vehicle supports Britton's (2005) view that OL is the individual and collective learning in the context of NGO which contributes to changes in individual and organizational behaviour. The Tarbiyah OL process in the organization lead the individuals to learn together, share knowledge and repertoire (Wenger, 1998) to update their mental models and to achieve the common objectives in their organization.

\section{Shared Vision}

One of the recurring themes in The Fifth Discipline is Senge's belief in the motivational effect of being part of something that is "larger than oneself" - of working for a common goal that transcends narrow self-interest (Hansen et al., 2020). This theme plays an important role in highlighting the importance of shared vision in an OL. Volunteerism with sincere self-satisfaction is an important concept in tarbiyah (education) in this Islamic-based NGO CoP activists (al-Aidan, 2010). All the voluntarily works and contributions of is because they want to get the pleasure of Allah SWT. This is very different from the reality where individual expecting a physical reward in this world. Respondent A explained how the satisfaction obtained through tarbiyah which relates to his contribution based on the concept of sincerity:

"... among the fundamental things emphasized in usrah is... you have to do it... sincerely ... not because of yourself ... but is to get the pleasure of Allah SWT ... as a result of our faith ... we will be rewarded with what we have done... more good deeds we do... we will have a better life in this world and in the hereafter ..."

Nurturing a shared vision among members of an organization is important in order to develop common goal and a strong team (Senge, 2006, p. 192). According to Britton (2005) an excellent organization relies heavily on leadership that motivates and stimulates subordinates as well as achieving the shared mission and vision of the organization. Tarbiyah as an organizational learning tool and mechanism that tie the members together can sustain the bonding among activists in the organization.

\section{Team Learning}

According to Senge (2006) another discipline in a learning organization is about team learning in which members learn together in the form of dialogue and discussion and these two significant activities are the cornerstone of Tarbiyah in the Islamic-based NGO (Hansen et al., 2020). The members master and develop their knowledge of their religion and the true way of life through listening and explaining to one another is a very collegial manner and practices. This tarbiyah is conducted within a community of practice as highlighted by Wenger (1998) who presented the CoP structure as consisting of three terms connected with one other namely: 1) mutual engagement with 2) responsibility for the organization and 3) sharing the repertoire.

The concept of CoP underlying this study is evidenced by tarbiyah of the Islamic-based NGO CoP activists through their mutual engagement, responsibility to the organization and sharing of the 
repertoire for the development of individuals, communities and organizations from an Islamic perspective. This mutual engagement refers to the tarbiyah within the Islamic-based NGO CoP activists whereby each of them learn to inculcate the Islamic values and practices in their daily lives. Tarbiyah also teaches the Islamic-based NGO CoP activists to develop themselves, their family and the larger communities around them. Tarbiyah contributes to the sharing of the repertoire consisting of knowledge, experience and resources among the Islamic-based NGO CoP activists. Respondent N narrated:

"... in the month of fasting we have a donation project to give bags of mercy to the needy ... we ask for donations with an estimated give to 60 poor people amounting to RM 6000 where each poor person receives RM 100. When the collections were made we got more that is RM 8000 ... we feel happy and satisfied. It is not only the tarbiyah that gives us satisfaction and pleasure. We have a relationship with the community in addition to experience interacting with other people ... there is so much enjoyment and feeling in delivering the good deeds (to the larger communities)..."

Thus, the Tarbiyah practiced in this Islamic-based NGO CoP activists comform to the way how CoP social learning model works (Wenger, 1998; Hamzah et. al, 2010) and the conduct of organizational leaning as a whole. Tarbiyah contribute to the sustainability of the NGO and is built on the solid foundation of a hidden force that cannot be seen with the naked eye (Shaikh Ahmad, 2004).

\section{Conclusion}

The solid foundation of tarbiyah of in the Islamic-based NGO CoP activists can be likened to the root of the organizational development that holds a tree from the underground. On the ground there are stem, branches, leaves, flowers and fruits that bring various benefits to the human being. This strong tree root analogy reflects the inner strength of Tarbiyah in this NGO CoP activists which form the strong 5 disciplines of a learning organization as emphasised by Senge (2006). Tarbiyah provided the boost for these Islamic NGO activists to always function as dedicated CoP members that consistently learn together and sustain their commitment to remain in the organization, ultimately continue understanding their purpose of life.

\section{Reference}

Al Ghazzali, A., H. (2020) Field, C. (translator). Alchemy of Happiness (reprint of 1910). Martino Fine Books: Eastford.

Boeije, H. R. (2002). A Purposeful Approach to the Constant Comparative Method in the Analysis of Qualitative Interviews. Quality \& Quantity. Vol. 36. pp. 391-409.

Britton, B. (2005). Organizational Learning in NGOs: Creating the motive, means and opportunity. The International NGO Training and Research Centre INTRAC.

Brown, J. S., Collins, A., \& Duguid, P. (1989). Situated cognition of the culture of learning. Educational Research, Vol 18 (1) 32-42.

Elsasser, S. (2014). Tarbiyah (Education) in the Muslim Brotherhood: Paper Presented at WOCMES, Angkara.

Hamzah, R., Isa, K. M., \& Janor, R. M. (2010). Spiritual education development model. Journal of Islamic and Arabic Education, 2(2), 1-12. 
Hansen, J, O., Jensen, A., Nguyen, N. (2020). Can Senge (1990) teach organizations how to become responsible innovators? The Learning Organization Vol. 27 No. 1, pp. 65-74.

Lave, J., \& Wenger, E. (1991). Situated Learning. Legitimate peripheral participation. UK: Cambridge University Press.

Merriam, S. B. (2009). Qualitative research: A guide to design and implementation. San Francisco, CA: Jossey Bass.

Moten, A. R. (2011). Leadership in the west an the Islamic world: A comparative analysis. World Applies Science Journal. 15 (3) 339-349.

Pyrko, I., Dorfler, V., Eden, C. (2017). Thinking Together: What makes Community of Practice Work? Human Relations. Vol. 70 (4), pp. 389-409

Senge, P. M. (1990). The art and practice of the learning organization.

Senge, P. M. (2006), The Fifth Discipline: The Art and Practice of the Learning Organization, Doubleday/ Currency, New York, NY.

Shaari, M. S., Jamaludin, Z. (2011). Towards an Islamic lifelong learning information system: A visionary Model of an Islamic Learning Community. Proceeding of the $3^{\text {rd }}$ International Conference on Computing and Informatics, ICOCI Bandung Indonesia.

Ahmad, S. M. (2004). Minimising mistake as a basis for holistic individual development, Telekom Training College, Kuala Lumpur.

Watkins, K. E., \& Marsick, V. J. (1997). Dimensions of the learning organization. Warwick, RI: Partners for the Learning Organization.

Wenger, E. (1998). Communities of practice: Learning, meaning and identity. Cambridge: Cambridge University Press, New York.

Wenger, E., \& Snyder, W. M. (2000). Communities of Practice: The Organizational Frontier: Harvard Business Review, 78 (1) 139 - 145 